\title{
Potential of Industrial Waste Water Use for Jatropha Cultivation in Arid Land
}

\author{
${ }^{1}$ Hanaa Hussein Abd El Baky, \\ ${ }^{2}$ Mohamed Moursy Hussein and ${ }^{1}$ Eman Ahamed Ibrahem \\ ${ }^{1}$ Department of Plant Biochemistry, National Research Centre, Dokki, Cairo, Egypt \\ ${ }^{2}$ Department of Water Relation and Irrigation, National Research Center, Dokki, Cairo, Egypt
}

Received 2013-10-12, Revised 2013-10-27; Accepted 2013-11-13

\begin{abstract}
A pot experiment was conducted in the greenhouse of the National Research Center, Dokki, Cairo, Egypt to investigate the effect of NKP foliar fertilizer and irrigation by Industrial Drainage Water (IDW) on Lipid Peroxidation (LP) and antioxidant enzyme activities [Catalase (CAT), Suproxide Desmatase (SOD) and Ascorbate Peroxidas (APX)] of jatropha plants. Plants fertilized with NPK fertilizers (N0g+P0g+K0g, $\mathrm{N} 3 \mathrm{~g}+\mathrm{P} 3 \mathrm{~g}+\mathrm{K} 3 \mathrm{~g}$ and $\mathrm{N} 6 \mathrm{~g}+\mathrm{P} 6 \mathrm{~g}+\mathrm{k} 6 \mathrm{~g} / \mathrm{pot})$ and irrigated by mixed varied levels of industrial drainage water $(0$, 25,50 and $75 \%$ IDW). Data showed that concentration of LP increased as percentage of IDW increased up to $75 \%$ and tended to decrease with water contains zero IDW. A positive relationship was observed between the CAT, SOD and APX enzyme activities and the level of IDW in irrigation water. The maximum values of the three enzymes activities were obtained with application of NPK: $2: 2: 2$ followed by application of NPK: 1:1:1 as compared with to the control. The highest lipid peroxidation were detected in leaves of non fertilized plants and irrigated by IDW, whereas the lowest values were detected in leaves of plants fertilized by NPK: 2:2:2 by fresh water.
\end{abstract}

Keywords: Jatropha (Jatropha Curcus L.), NPK, Combined Fertilizers with Industrial Drainage Water, Lipid Peroxidation, Antioxidant Enzymes Activities

\section{INTRODUCTION}

The genus Jatropha (Euphorbiaceae) comprises of about 170 species of woody trees, shrubs, sub shrubs or herbs in the seasonally dry tropics of the Old and the New World. They are used in medicinal folklore to cure various diseases of $80 \%$ of the human population in Africa, Asia and Latin America. Species from this genus have been popular to cure stomachache, inflammation, dysentery, vertigo, anemia, diabetis, as well as to treat HIV and tumor (Sabandar, 2013). They are also employed as ornamental plants and energy crops for production biodiesel (Sabandar et al., 2013).

Biodiesel is alternative fuel for diesel engines, are becoming increasingly important due to diminishing petroleum reserves and the environmental consequences of exhaust gases from petroleum-fuelled engines (Raja et al., 2011). However, biodiesel is a locally-available source of energy that not only can provide energy to meet the increased energy demand derived from the economic development of developing countries. But, also contributes to climate change mitigation and rural development. Jatropha curcas (Fam. Euphorbiaceae) plant has been acknowledged as the preferred crop for the purpose which is drought resistant, perennial and fast growing on poor soil (Misra and Misra, 2010). Jatropha curcas L is a small tree with spreading branches and stubby twigs that grows to 20 feet high under favorable conditions. When propagated from seed five roots are formed-one tap root and 4 lateral roots. Plants propagated from cuttings normally develop only lateral roots with one perhaps developing into a psudo-tap root that may reach only $1 / 2$ to $2 / 3$ the length of a normal tap root. Jatropha has both male and female plants, which may produce different yields of nuts. Dormancy is induced by fluctuations in rainfall and temperature/light; nevertheless, not all trees respond simultaneously. In a hedge you may have branches without leaves beside ones full of green leaves. The life-span of Jatropha may Corresponding Author: Hanaa Hussein Abd El Baky, Department of Plant Biochemistry, National Research Centre, Dokki, Cairo, Egypt 
be more than 50 years; however, termites are reported to attack older trees.

There is a growing interest in Jatropha curcas as a biodiesel "miracle tree" to help alleviate the energy crisis and generate income in rural areas of developing countries. Jatropha is becoming a poster child among some proponents of renewable energy and appropriate technology, especially as an oil-bearing, "drought resistant" tree for marginal lands for small farmers (Benge, 2006).

Several researches have been done for the possibility of use of poor quality water in trees production: (Pescod, 1992; Parsons et al., 2001; Achten, 2010). Under unflavored condition, reactive oxygen species such as superoxide radical, $\mathrm{H}_{2} \mathrm{O}_{2}$ and $\mathrm{OH}$ radicals have a role in lipid peroxidation that lead to membrane damage and degraded of bio molecules such as proteins, phospholipids and pigments. Antioxidant protection involves compounds such as carotenoids, ascorbic acid, atocopherol, phenolics and flavonoids (Abd El-Baky et al., 2010) and a number of enzymes including Superoxide Dismutase (SOD) and Ascorbate Peroxidase (APX), Catalase (CAT) and Glutathione Reductase (GR) are believed to play a crucial role in scavenge of different free radical (Abd El-Baky et al., 2008). Fertilization as a one from successful mean for depressing the damages caused from use of poor quality water was reported by many authors: (Hussein 2008; Segala et al., 2011; Mazhar et al., 2011). El-Kadi and Kamed (2004) stated that fertilizer led to effects in oxidative defense enzymes in fruit trees. Fertilizer reduction leads to production of oxygen radicals, which results to oxidative stress in the plant and the application of super absorbent polymer could conserve soil water and nutrients, making same available for plants to reduce oxidative stress and increase biomass accumulation, especially under reduced fertilization level (Zhang et al., 2011).

Therefore, this study aimed to study the effect of combined fertilizers and irrigation by mixed drainage water on enzymes of oxidative defense of jatropha plants.

\section{MATERIALS AND METHODS}

Pot experiments were carried out in a greenhouse during the 2011 summer season at the National Research Center (NRC), Dokki, Giza governorate, Egypt to evaluate the effect of NPK fertilizers and irrigation by different percentage of mixed industrial drainage water with fresh water on antioxidant enzyme activities in leaves of jatropha plants. The treatments were as follows:

- Jatropha plants irrigated with mixture drainage water: Fresh water, (25: 75, v:v), (50:50, v:v) and (75: 25, v:v) and Jatropha plants irrigated with 100 $\%$ fresh water
- Application with fertilizer: The plants were fertilizer without mineral fertilizers, the plants were fertilizer with NPK at two different levels $(1: 1: 1$ and $2: 2: 2 \mathrm{w} / \mathrm{w} / \mathrm{w})$

The experiment included 3 percentages of mixed drainage water in combination with three foliar fertilizer treatments i.e., 12 treatments in 6 replicates. A 36 pots of $35 \mathrm{~cm}$ in diameter and $50 \mathrm{~cm}$ deep were used, each pot were contained $30 \mathrm{~kg}$ of air dried clay loam soil (The physical (a) and chemical (b) properties is shown in Table 1). Jatropha seeds (Jatropha curcus L.) were sown at May, 1, 2011 in the summer season. Plants were thinned twice, the 1st days after sowing and the 2nd two weeks later to leave three plants/pot. Calcium super phosphate $\left(15.5 \% \mathrm{P}_{2} \mathrm{O}_{5}\right)$ and potassium sulfate $(48.5 \%$ $\mathrm{KO}_{2}$ ) as treatments were added before sowing. Ammonium sulfate $(20.5 \% \mathrm{~N})$ as a treatment was added in two equal portions, the 1st after two weeks of transplanting and the 2nd two weeks later. Irrigation with mixed drainage water (the quality of IDW is shown in Table 2) at different concentrations was started 21days after sowing (one irrigation by mixed drainage water and the next irrigation by fresh water only alternatively.

\subsection{Enzyme Activity Assay}

\subsubsection{Extraction of Cytosolic Fraction}

A plant material (ca. $2 \mathrm{~g}$ ) was excised and homogenized in $10 \mathrm{~mL}$ of ice-cold grinding buffer containing $0.4 \mathrm{M}$ sucrose and $25 \mathrm{mM}$ Tris ( $\mathrm{pH}$ 7.2). The homogenate was passed through 4 layers of cheat cloth and centrifuged at $12,000 \times \mathrm{g}$ for $15 \mathrm{~min}$ at $4{ }^{\circ} \mathrm{C}$. The resulting supernatant was used for determination of enzyme activities, lipid oxidation products and protein contents.

\subsection{Enzyme Assays}

The activities of Jatropha leaves cytosolic Superoxide Dismutase (SOD; EC, 1.15.1.1) was determined as described by Maehly and Chance (1954). The activity of Ascorbate Peroxidase (APX), (EC, 1.11.1.11) was assayed according to Nakano and Asada (1981). The activity of each enzyme was expressed on protein basis.

\subsection{Determination of Lipid Peroxidation Products}

The lipid peroxidation products in Jatropha leaves cytosolic fraction were estimated by the formation of Thiobarbaturic Acid Reactive Substances (TBARS) and quantified in term of Malonaldhyde (MDA) as described by Haraguchi et al. (1997). The lipid peroxidation was expressed as micromoles of MDA calculated using the extinction coefficient of $1.56 \times 10^{5} \mathrm{mM}^{-1} \mathrm{~cm}^{-1}$. 
Table 1. Physical and chemical analysis of the soil used in pot experiment

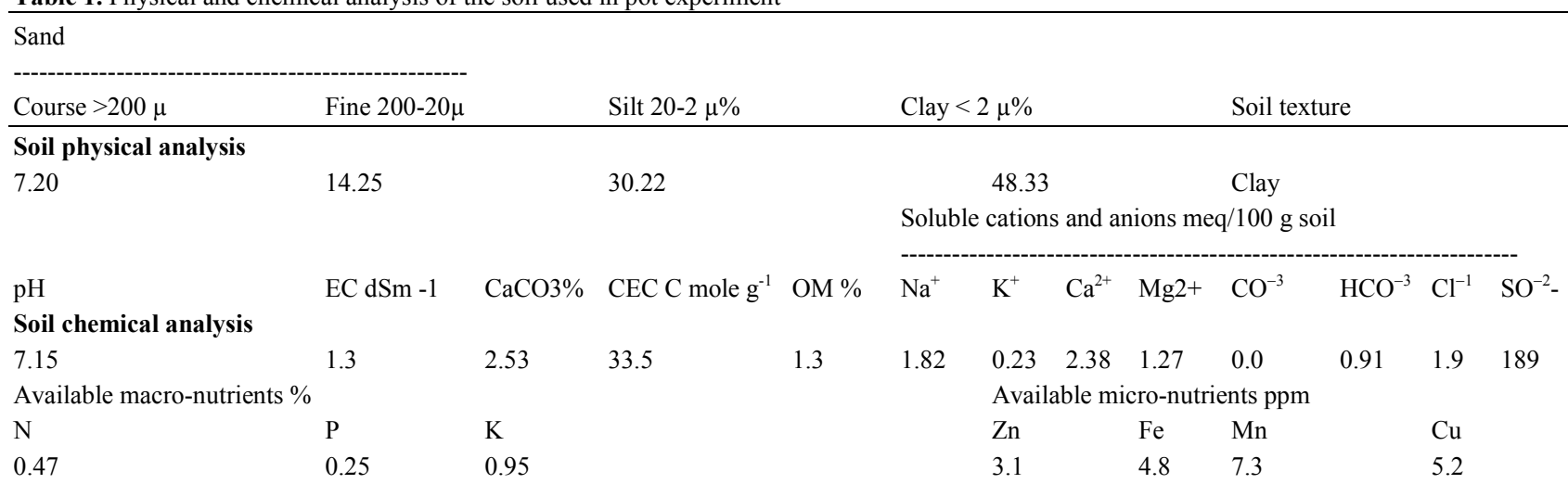

Table 2. Industrial drainage water analysis

\begin{tabular}{ll}
\hline Parameters & Values \\
\hline $\mathrm{pH}$ & 7.19 \\
$\mathrm{EC}\left(\mathrm{dS} / \mathrm{m}^{-1}\right)$ & 1.12 \\
Soluble cations $(\mathbf{m e q} / \mathbf{L})$ & \\
$\mathrm{Ca}^{++}$ & 2.50 \\
$\mathrm{Mg}^{++}$ & 2.50 \\
$\mathrm{Na}^{+}$ & 6.50 \\
$\mathrm{~K}^{+}$ & 2.00 \\
Soluble anions (meq/L) & \\
$\mathrm{Co}^{3-}$ & - \\
$\mathrm{HCO}^{3-}$ & 5.90 \\
$\mathrm{CL}^{-}$ & 5.00 \\
$\mathrm{SO}^{4-}$ & 0.80 \\
\hline
\end{tabular}

\subsection{Determination of Soluble Protein}

The total protein content in wheat cytosolic fraction was determined at $595 \mathrm{~nm}$, using Comassein blue G 250 as mentioned by Bradford (1979). Bovine Serum Albumin (BSA) was used as a protein standard.

\subsection{Statistical Analysis}

Results were statistical analyzed by as methods described by: Snedecor and Cochran (1989).

\section{RESULTS}

\subsection{Affect of Nitrogen, Phosphorus and Potassium Ratio on Lipid Peroxidation and Oxidative Enzymes Activities in Leaves of Jatropha Plants}

The activities of antioxidant enzymes Catalase (CAT), Ascorbate Peroxidase (APX) and Superoxide Dismutase (SOD) in leaves of Jatropha plant fertilizer with nitrogen, phosphorus and potassium by two ratios are shown in Table 3 . The activities of the antioxidant enzymes CAT, SOD and APX presented differential response pattern to nitrogen, phosphorus and potassium by two ratios fertilization (NPK:1:1:1 and NPK2 :2:2). The highest enzymes activities of CAT, SOD and APX was occurred in leaves of jatropha plants fertilized by the highest ratio of NPK2: $2: 2$, with values $81.2,45.5$ and $39.98 \mu \mathrm{moL} \mathrm{g}{ }^{-1}$ $\mathrm{FW} / \mathrm{min}$, respectively. Both CAT and SOD activities in leaves plants increased as increasing the ratio of NPK fertilization.

Lipid Perioxidation (LP) gave its higher value (56.85 $\mu \mathrm{moL} \mathrm{gfw}^{-1}$ ) when jatropha plant had no fertilizer NPK and tended to decreased leaves of jatropha plants fertilized by the highest ratio of

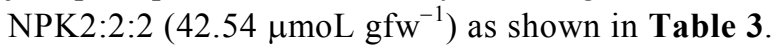

\subsection{Effect of Irrigation by Industrial West Water on Lipid Peroxidation and Antioxidant Enzyme Activities}

Lipid Perioxidation (LP) gave its higher value when Industrial West water (IDW) added in the rate of $75 \%$ and tended to decreased, but still more than the control. However the similar levels of LP were obtained in

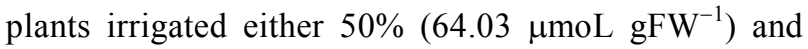
$75 \%$ mixed water $\left(75.0 \mu \mathrm{moL} \mathrm{gFW}^{-1}\right)$ (Table 4).

The activities of antioxidant enzymes Catalase (CAT), Ascorbate Peroxidase (APX) and Superoxide Dismutase (SOD) in leaves of Jatropha plant irrigation by Industrial West water (IDW) are shown in Table 4. The activities of the antioxidant enzymes CAT, SOD and APX presented differential response pattern to irrigated of water conditions. The highest enzymes activities of CAT, SOD and APX was occurred in leaves of jatropha plants irrigated with the highest level of $75 \%$ IDW, with values $93.68,57.14$ and 39.90 $\mu \mathrm{mol} \mathrm{g}{ }^{-1} \mathrm{FW} / \mathrm{min}$, respectively. Both CAT and SOD activities in leaves plants increased as increasing the levels of IDW in the water of irrigation up to the highest level used (75\%). 
Table 3. Affect of nitrogen, phosphorus and potassium ratio on lipid peroxidation and oxidative enzymes activities in leaves of jatropha plants

\begin{tabular}{lllcc}
\hline & LP & CAT & SOD & APX \\
& TBARs & $\mu \mathrm{mol} / \mathrm{g}$ & $\mu \mathrm{mol} / \mathrm{g}$ & $\mu \mathrm{mol} / \mathrm{g}$ \\
Fertilizer & $\mu \mathrm{mol} / \mathrm{gFW}$ & $\mathrm{FW} / \mathrm{min}$ & $\mathrm{FW} / \mathrm{min}$ & $\mathrm{FW} / \mathrm{min}$ \\
\hline Zero NPK & 56.84 & 68.85 & 36.58 & 30.84 \\
NPK 1:1:1 & 50.56 & 75.50 & 45.50 & 34.59 \\
NPK2:2:2 & 42.54 & 81.20 & 45.50 & 39.98 \\
LSD at $5 \%$ & $\mathrm{~N} \%$ & $\mathrm{~N} . \mathrm{S}$ & 4.83 & $\mathrm{~N} . \mathrm{S}$ \\
\hline
\end{tabular}

Zero NPK = Without mineral fertilizer; NPK1:1:1 = 3g N+3g P+3g; K/pot NPK2:2:2 = 6N+6g P+6g K/pot

Table 4. Affect of Industrial drainage water on lipid peroxidation and oxidative enzymes activities in leaves of jatropha plants

\begin{tabular}{llccc}
\hline $\begin{array}{l}\text { Industrial } \\
\text { drainage water }\end{array}$ & LP & CAT & SOD & APX \\
$(\%)$ & TBARs & $\mu \mathrm{mol} / \mathrm{g}$ & $\mu \mathrm{mol} / \mathrm{g}$ & $\mu \mathrm{mol} / \mathrm{g}$ \\
\hline Zero & $\mu \mathrm{mol} / \mathrm{gFW}$ & $\mathrm{FW} / \mathrm{min}$ & 27.83 & $\mathrm{FW} / \mathrm{min}$ \\
25 & 56.84 & 44.62 & 38.53 & 24.66 \\
50 & 57.79 & 75.39 & 51.79 & 30.49 \\
75 & 64.03 & 87.04 & 57.14 & 35.81 \\
LSD at 5\% & 75.00 & 93.68 & 4.830 & 39.90 \\
\hline
\end{tabular}

Table 5. Effect of NPK fertilization and irrigation by mixed industrial drainage water on lipid peroxidation and oxidative enzymes activities in leaves of jatropha plants

\begin{tabular}{|c|c|c|c|c|c|}
\hline $\begin{array}{l}\text { Industrial } \\
\text { drainage water } \\
(\%)\end{array}$ & $\begin{array}{l}\text { Fertilizer } \\
\text { NPK }\end{array}$ & $\begin{array}{l}\text { LP } \\
\text { TBARs } \\
\mu \mathrm{mol} / \mathrm{gFW}\end{array}$ & $\begin{array}{l}\text { CAT } \\
\mu \mathrm{mol} / \mathrm{g} \\
\mathrm{FW} / \mathrm{min}\end{array}$ & $\begin{array}{l}\text { SOD } \\
\mu \mathrm{mol} / \mathrm{g} \\
\mathrm{FW} / \mathrm{min}\end{array}$ & $\begin{array}{l}\text { APX } \\
\mu \mathrm{mol} / \mathrm{g} \\
\mathrm{FW} / \mathrm{min}\end{array}$ \\
\hline \multirow[t]{3}{*}{ Zero } & Zero NPK & 42.89 & 32.78 & 24.78 & 23.38 \\
\hline & NPK $1: 1: 1$ & 44.67 & 43.62 & 32.17 & 26.08 \\
\hline & NPK2:2:2 & 41.27 & 57.47 & 26.55 & 24.52 \\
\hline \multirow[t]{3}{*}{25} & Zero NPK & 64.18 & 54.05 & 40.68 & 30.20 \\
\hline & NPK $1: 1: 1$ & 58.77 & 65.78 & 59.23 & 49.91 \\
\hline & NPK2:2:2 & 50.41 & 76.34 & 65.68 & 54.94 \\
\hline \multirow[t]{3}{*}{50} & Zero NPK & 88.65 & 74.67 & 50.86 & 35.81 \\
\hline & NPK $1: 1: 1$ & 76.31 & 89.59 & 55.86 & 54.94 \\
\hline & NPK2:2:2 & 64.87 & 96.85 & 78.66 & 77.64 \\
\hline \multirow[t]{3}{*}{75} & Zero NPK & 95.33 & 89.32 & 57.22 & 44.17 \\
\hline & NPK $1: 1: 1$ & 87.98 & 92.11 & 73.28 & 64.74 \\
\hline & NPK2:2:2 & 76.54 & 109.43 & 81.93 & 88.87 \\
\hline LSD at $5 \%$ & & 2.370 & N.S & 4.83 & N.S \\
\hline
\end{tabular}

Zero NPK = Without mineral fertilizer; NPK1:1:1 = 3g N+3g P+3g; K/pot NPK2:2:2 = 6N+6g P+6g K/pot

\subsection{Influence of NPK Fertilizer Combined with Irrigation by Industrial Drainage Water on Lipid Peroxidation and Oxidative Enzymes Activities in Leaves of Jatropha Plants}

The interactive effect between irrigation by mixed industrial drainage water and NPK fertilizer data showed in Table 5. Lipid Perioxidation (LP) gave its higher value when Industrial West Water (IDW) added in the rate of $75 \%\left(95.33 \mu \mathrm{mo}^{-1} \mathrm{gFW}^{-1}\right)$ and tended to decreased, when irrigation with Industrial West water (IDW) combined with NPK fertilizer at level NPK2:2:2 $\left(76.54 \mu \mathrm{mo}^{-1} \mathrm{gFW}^{-1}\right)$ but still more than the control $\left(42.89 \mu \mathrm{moL} \mathrm{gFW}^{-1}\right)$. However the similar levels of LP were obtained in plants irrigated either 50\% and fertilized with NPK 1:1:1 (76.31 $\left.\mu \mathrm{moL} \mathrm{gFW}^{-1}\right)$. Data in the same Table 5 indicated that the positively affected of antioxidant enzymes (CAT, SOD and APX) activity under different irrigation levels of IDW treatment combined with NPK fertilizer at two levels. The highest antioxidant enzyme activities (CAT, SOD and APX) found when Jatropha plants irrigated with IDW at $75 \%$ and fertilized by NPK: 2:2:2 (109.43, 81.93 and $88.87 \mu \mathrm{moL} \mathrm{gFW}^{-1}$ ). Also, it was observed that the effect decreased parallel to the increase of IDW $\%$ in irrigation solution and the values of activity were higher with the addition of NPK fertilizer. Furthermore, CAT and APX clearly showed approximately similar 
response of CAT enzyme activity except when plants irrigated with water contains $75 \%$ IDW which it was negatively responded.

\section{DISCUSSION}

Drainage water contains salts and heavy metals in varied degrees led to oxidative stress in plant irrigated with waters and cause several physiological changes due to chance in metabolic pathway (Lee et al., 2001; Panda and Upadhyay, 2003). Production of several Active Oxygen Species (AOS) increases in the presence of $\mathrm{NaCl}$ and has been stated to damage almost every macromolecule (Khan and Panda, 2002). However, in many plant cells exposed to oxidative stress the led to induction of both enzymatic (Superoxide Dismutase; (SOD), Catalase; (CAT), Ascorbate Peroxidase; (APO) and Glutathione Reductase; GR) and non-enzymatic (ascorbate, glutathione and alpha tocopherol) antioxidant defense systems, which help in detoxifying the AOS (Lee et al., 2001; Malencic et al., 2003; Akbari et al., 2011). Application of urea to $\mathrm{NaCl}$-stressed lettuce plants can, at least, partially counteract the stressinduced damage, is also associate by detailed changes in wide array of metabolitic pathway including antioxidant enzymes (Abd El-Baky et al., 2010). Akbari et al. (2011) stated that $\mathrm{NaCl}$ stress increased the endogenous, nonenzymatic antioxidants and the activity of antioxidant enzymes, such as peroxidase, superoxide and catalase. Similarly, Golpayegani and Tilebeni (2011) and Abd El-Baky et al. (2008) could be induce in plants or microalgae in response to stressors such as salinity, to protect against oxidative stress, plant cells produce antioxidant enzymes such as SOD, POD, CAT and APX.

Ahn et al. (2005) suggested that antioxidant enzyme activities may be influenced by the availability of phosphorus, but are subject to considerable variation depending on the developmental stage and the season. Leja et al. (2007) found that activity against free radical was increased with nitrogen fertilizer from different sources (Ammonium nitrate, urea and ammonium sulfate) except calcium nitrate which led to decrease this activity. Nitrogen supply prevents oxidative stress in roots, but may improve root development and increase the uptake of $\mathrm{Hg}$ from the soil above safety consumption limits. This study highlights the importance of proper nitrogen fertilization towards future phyto-remediation applications with alfalfa plants (Gil et al., 2012). Cakmak and Horst (1991) indicate that increases in ROS production during both photosynthetic electron transport and NADPH-oxidizing enzyme reactions may be involved in membrane damage and chlorophyll degradation in $\mathrm{K}$ deficient plants. In good agreement with this suggestion, increases in severity of $\mathrm{K}$ deficiency were associated with enhanced activity of enzymes involved in detoxification of $\mathrm{H}_{2} \mathrm{O}_{2}$ (ascorbate peroxidase) and utilization of $\mathrm{H}_{2} \mathrm{O}_{2}$ in oxidative processes. Moreover, $\mathrm{K}$ deficient plants are highly lightsensitive and very rapidly become chlorotic and necrotic when exposed to high light intensity. In view of the fact that ROS production by photosynthetic electron transport and NADPH oxidases is especially high when plants are exposed environmental stress conditions, it seems reasonable to suggest that the improvement of $\mathrm{K}$ nutritional status of plants might be of great importance for the survival of crop plants under environmental stress conditions, such as drought, chilling and high light intensity. Several examples are presented here emphasizing the roles of $\mathrm{K}$ in alleviating adverse effects of different abiotic stress factors on crop production. Kant et al. (2007) mentioned that the $\mathrm{NH}_{4}{ }^{+} / \mathrm{NO}_{3}{ }^{-}$regime led to an increase in total $\mathrm{N}$ in control and saline treatments, but did not cause a large decrease in plant $\mathrm{Na}^{+}$ content under salinity. Activities of GS (EC 6.3.1.2), GOGAT (EC 1.4.1.14), PEPC (EC 4.1.1.31) and AAT (EC 2.6.1.1) increased with salinity in roots, whereas there was decreased activity of the alternative ammonium assimilation enzyme GDH (EC 1.4.1.2). Several authors observed the interactive effect of fertilizer and moisture condition on metabolism of plants (Younis et al., 2008; Zhang et al., 2011; Mao et al., 2011).

Fertilizer reduction leads to production of oxygen radicals, which results to oxidative stress in the plant and the application of super absorben polymer could conserve soil water and nutrients, making same available for plants to reduce oxidative stress and increase biomass accumulation, especially under reduced fertilization level (Zhang et al., 2011).

\section{CONCLUSION}

Our results indicate that, even if oxidative stress is induced in jatropha plants irrigated with 25,50 and $75 \%$ industrial west water, application of NPK could be provide protection against this oxidative stress by increase the antioxidant protective system, which involved as one of the factor responsible for salt tolerance of Jatropha plants. Therefore, the irrigation of Jatropha plants by mean of industrial west water at $75 \%$ $(\mathrm{v} / \mathrm{v})$ is possible when fertilized with NPK.

\section{REFERENCES}

Abd El-Baky, H.H., F.K. El Baz and G.S. El-Baroty, 2010. Enhancing antioxidant availability in wheat grains from plants grown under seawater stress in response to microalgae extract treatments. J Sci. Food Agric., 90: 299-303. DOI: $10.1002 /$ jsfa.3815 
Abd El-Baky, H.H., M.M. Hussein and G.S. El-Baroty, 2008. Algal extracts improve antioxidant defense abilities and salt tolerance of wheat plant irrigated with sea water. Afr. J. Biochem. Res., 2: 151-164.

Achten, W., 2010. Sustainability evaluation of biodiesel from Jatropha curcas L.-A life cycle oriented study. $\mathrm{PhD}$ Thesis, KU Leuven.

Ahn, T., M. Oke, A. Schofield and G. Paliyath, 2005. Effects of phosphorus fertilizer supplementation on antioxidant enzyme activities in tomato fruits. J Agric Food Chem., 53: 1539-1545. PMID: 15740037

Akbari, G.A., M. Hojati, S.A.M. Modarres-Sanavy and F. Ghanati, 2011. Exogenously applied hexaconazole ameliorates salinity stress by inducing an antioxidant defense system in Brassica napus L. plants. Pesticide Biochem. Physiol., 100: 244-250. DOI: 10.1016/j.pestbp.2011.04.008

Benge, M., 2006. Assessment of the potential of Jatropha curcas, (biodiesel tree,) for energy production and other uses in developing countries. Forestry Officer USAID (Ret.).

Bradford, M.M., 1979. A rapid and sensitive method for the quantitation of microgram quantities of protein utilizing the principle of protein-dye binding. Anal. Biochem., 72: 248-254. PMID: 942051

Cakmak, I. and J. Horst, 1991. Effect of aluminium on lipid peroxidation, superoxide dismutase, catalase and peroxidase activities in root tips of soybean (Glycine max). Physiol Plant, 83: 463-468. DOI: 10.1111/j.1399-3054.1991.tb00121.x

EL-Kadi, M.A. and R. Kamed, 2004. Fertilization of fruit trees grown in newly reclaimed areas of egypt with potassium as SOP balanced with nitrogen and phosphorus. Proceedigns of the IPI Regional Workshop on Potassium and Fertigation development in West Asia and North Africa, Nov. 24-28, Rabat Morocco, pp: 1-8.

Gil, S.C., M.E. Yubero, D.M. Cuesta, R. Millan and L.E. Hernandez, 2012. Influence of nitrate fertilization on $\mathrm{Hg}$ uptake and oxidative stress parameters in alfalfa plants cultivated in a $\mathrm{Hg}$-polluted soil. Environ. Exp. Botany, 75: 16-24. DOI: 10.1016/j.envexpbot.2011.08.013

Golpayegani, A. and H.G. Tilebeni, 2011. Effect of biological fertilizers on biochemical and physiological parameters of basil (Ociumum basilicm L.) medicine plant. Am. Eurasian J. Agric. Environ. Sci.,11: 445e-450e.

Haraguchi, K., Y. Kato, R. Kimura and Y. Masuda, 1997. Comparative study on formation of hydroxy and sulfur-containing metabolites from different chlorinated biphenyls with 2,5-substitution in rats. Drug Metab Dispos., 25: 845-852. PMID: 9224779
Hussein, A.H.A., 2008. Response of manzanillo olive (Olea europaea L.) cultivar to irrigation regime and potassium fertigation under tabouk conditions. Saudi Arabia J. Agron., 7: 285-296. DOI: 10.3923/ja.2008.285.296

Kant, S., P. Kant, K. Lips and S. Barak, 2007. Partial substitution of $\mathrm{NO}(3)(-)$ by $\mathrm{NH}(4)(+)$ fertilization increases ammonium assimilating enzyme activities and reduces the deleterious effects of salinity on the growth of barley. J. Plant Physiol., 3: 303-311. PMID: 16545490

Khan, M.H. and S.K. Panda, 2002. Induction of oxidative stress in roots of oryza sativa 1 . in response to salt stress. Biol. Plantarum, 45: 625-627. DOI: 10.1023/A:1022356112921

Lee, H.D., Y.S. Kim and C.B. Lee, 2001. The inductive responses of the antioxidant enzymes by salt stress in the rice (Oryza sativa L.). J. Plant Physiol., 158: 737-745. DOI: 10.1078/0176-1617-00174

Leja, M., G. Wyzgolik and I. Kaminska, 2007. Some parameters of antioxidant capacity of red cabbage as related to different forms of nutritive nitrogen. J. Folia Horticul., 19: 15-23.

Maehly, A.C. and B. Chance, 1954. The assay of catalases and peroxidases. Methods Biochem. Anal., 1: 357-424. PMID: 13193536

Malencic, D.J., M. Popovic and J. Miladinovic, 2003. Stress tolerance parameters in different genotypes of soybean. Biol. Plant, 46: 141-143. DOI: 10.1023/A:1022384600538

Mao, S., M.R. Islam, Y. Hu, X. Qian and F. Chen et al., 2011. Antioxidant enzyme activities and lipid peroxidation in corn (Zea mays L.) following soil application of superabsorbent polymer at different fertilizer regimes. Afr. J. Biotechnol., 10: 1000010008. DOI: $10.5897 / A J B 11.1348$

Mazhar, A.A., G.N. Abdel-Aziz, S. ShI and S.M. Zaghloul, 2011. Effect of Nile Compost application on growth and chemical constituents of Jatropha curcas grown under different salinity levels of diluted sea water. Aus. J. Basic Applied Sci., 5: 967-974.

Misra, M. and N.A. Misra, 2010. Jatropha: The biodiesel plant biology, tissue culture and genetic transformation-a review. Int. J. Pure Applied Sci. Technol., 1: 11-24.

Nakano, Y. and K. Asada, 1981. Hydrogen peroxide is scavenged by ascorbate-specific peroxidase in spinach chloroplasts. Plant Cell Physiol., 22: 867880 .

Panda, S.K. and R.K. Upadhyay, 2003. Salt stress injury induces oxidative alterations and antioxidative defiance in the roots of Lemna minor. Biol. Plantarum, 48: 249-253.

Parsons, L.R., T.A. Wheaton and C.T. Castle, 2001. High application rates of reclaimed water benefit citrus tree growth and fruit production. Hort. Sci., 36: 1273-1277. 
Pescod, M.B., 1992. Wastewater Treatment and Use in Agriculture. 1st Edn., Food and Agriculture Organization of the United Nations, Rome, ISBN10: 9251031355 , pp: 125 .

Raja, S.A., D.S. Robinson and C.R. Lindon, 2011. Biodiesel production from jatropha oil and its characterization. Res. J. Chem. Sci., 1: 81-87.

Sabandar, C.W., 2013. Medicinal property, phytochemistry and pharmacology of several Jatropha species (Euphorbiaceae): A review. Phytochemistry, 85: 7-29. DOI: 10.1016/j.phytochem.2012.10.009

Sabandar, C.W., N. Ahmat, F.M. Jaafar and I. Sahidin, 2013. Medicinal property, phytochemistry and pharmacology of several Jatropha species (Euphorbiaceae): A review. Phytochem, 85: 7-29. PMID: 23153517

Segala, E., A.A. Daga, I. Ben-Gala, S. Ziporia and R. Erela et al., 2011. Olive orchard irrigation with reclaimed wastewater: Agronomic and environmental considerations. Agric. Ecosyst. Environ., 140: 454-461.
Snedecor, G.W. and W.G. Cochran, 1989. Statistical Methods. 1st Edn., Iowa State University Press, Ames, ISBN-10: 0813815614, pp: 503.

Younis, M.E., N.A. Hasaneen, R. Adel, A.R. Ahmed and D.M. El-Bialy, 2008. Plant growth, metabolism and adaptation in relation to stress conditions. XXI. Reversal of harmful $\mathrm{NaCl}$-effects in lettuce plants by foliar application with urea. Southern Cross J., 2: 83-95.

Zhang, M., Z. Wang, J. Xu, Y. Liu and L. Ni et al., 2011. Ammonium, microcystins and hypoxia of blooms in eutrophic water cause oxidative stress and $\mathrm{C}-\mathrm{N}$ imbalance in submersed and floating-leaved leaved aquatic plants in Lake Taihu, China. Chemosphere, 82: 329-339. PMID: 21075418 